\title{
The New England Renaissance and American Literary Ethnocentrism
}

\section{Citation}

Buell, Lawrence. 1985. The New England renaissance and American literary ethnocentrism.

Prospects 10: 409-422.

\section{Published Version}

doi:10.1017/S0361233300004166

\section{Permanent link}

http://nrs.harvard.edu/urn-3:HUL.InstRepos:3627851

\section{Terms of Use}

This article was downloaded from Harvard University's DASH repository, and is made available under the terms and conditions applicable to Other Posted Material, as set forth at http:// nrs.harvard.edu/urn-3:HUL.InstRepos:dash.current.terms-of-use\#LAA

\section{Share Your Story}

The Harvard community has made this article openly available.

Please share how this access benefits you. Submit a story.

Accessibility 


\title{
The New England Renaissance and American Literary Ethnocentrism
}

\section{LAWRENCE BUELL}

\begin{abstract}
Thank Heaven, you are a Yankee still. For my own part, 1 fear I would never be entirely contented to spend my days. out of New Ergiand. Where first rose the sun of my being' there I would have it set.
\end{abstract}

- Whittier, Letters (1832)

that worst of all cant, the cant of New Englandism

- Peter Oliver, The Puritcin Commonwealth (1856)

\begin{abstract}
TUST AS PATRIOT ORATORS INvOKED the spirit of Puritanisin in their remonstrances against British tyranny, just as the nineteenth-century cult of Pilgrimism taught all America to look back upon the Pilgrim fathers as everyone's fathers, so modern American intellectual history has proclaimed the Puritan origins of the American way. The result has been a scholarly upsurge, during the past half-century, of "Puritan legacy" studies, of which Perry Miller was the prime mover and Sacvan Bercovitch is the leading contemporary theorist. ${ }^{1}$ So far as the interpretation of literary history is concerned, these studies have given a new authority and depth to the old New England-centered map of American literary tradition first drawn up by the Yankee-oriented. genteel intellectual establishment of the late nineteenth century that presided over the literary institutions whose prestige had been built: upon the reputation of the perpetrators of the antebellum New England. Renaissance. ${ }^{2}$ The old-fashioned interpretation of American literary history and the new-fashioned interpretation of American civil religion as a nationalized version of Puritan ideology have combined to create a strong presumption, at least for specialists in New England Romantic literature, that theirs was the key formative moment in American literary history as a whole.
\end{abstract}


This last observation is partly an autobiographical statement. As a long-term student of the New England sensibility in its various phases, I am predisposed to put American culture under the sign of Puritanism - to think of Emerson, Hawthorne, Thoreau, Dickinson, and Harriet Beecher Stowe as having been responsible for generating and transmitting to posterity much that is characteristic of subsequent American poetry and prose, characteristics profoundly affected by their literary reinvention of their Puritan antecedents. ${ }^{3}$ At the same time, with one eye on the increasing number of other subcultures that have reached literary maturity in this century, I am mindful of the increasingly formidable array of hostile tribes one must kill off in order to consolidate the empire of American culture under a Puritan rubric. Others have raised more strenuous objections than I at this point, suggesting that Puritan legacy-ism might be nothing more than an artifact of the researcher's wishful hope to break through to a unified theory of American culture. ${ }^{4}$ My own desire is not to bite a hand that has fed me intellectually but to search for a theory of the New England impress on American culture that will do justice to its ongoing power-its ability, for example, to make both scholars and ordinary non-New Englanders think of modern America as Pilgrim-descended - and yet stand up under critical examination in light of the facts of late twentieth-century American culture, which looks increasingly pluralistic and remote from its era of New England hegemony. Certainly as we move toward the twenty-first century it will become increasingly necessary to retell the saga of American literature in such a way as to account for Russian emigré Vladimir Nabokov, Native American storyteller Leslie Silko, and Chicano novelist Rudolfo Anaya, not to mention the large body of contemporary Jewish American and black American writing that has accounted for much of the vitality of contemporary letters.

One obvious way of compensating for the temptation to overgeneralize about the cultural importance of post-Puritan New England influences in the face of an increasingly pluralistic American reality is to demystify the former as a provincial ideology-however far-reaching its aspirations, however wide its prestige-and thus substantially on the same footing with America's other regional and minority cultures, though at a historical advantage because of its early start and its early strength. In this view, any continuities between, say, Hawthorne's Puritans and Malamud's urban Jews would not be understood in terms of the Puritan origins of the American sense of loneliness and chosenness so much as in their common situations-or common self-images-as members of an embattled remnant that has felt forced to contend against a hostile environment in order to preserve cherished values and cultural identity.

To classify New England Renaissance literature as a manifestation of provincial consciousness is not a very popular or respectable diagnosis. For one thing, although American literary scholarship has always 
been attracted to the idea of subculturation-both regional and ethnic - as a key to understanding American civilization, such scholarship also has been widely regarded as superficial or as compromised by special pleading. Despite Hamlin Garland's ringing affirmation that "local color in fiction is demonstrably the life of fiction," for all the talk of a "new regionalism" during the last fifty years, the impression persists that that regionalism ought to be regarded as a trivial aspect of American literary history; that good writers transcend it; that they are good precisely in proportion to the degree that they transcend it; that anything valid about Garland's affirmation is truistical; and that to concentrate on the element of regional - if not minority-consciousness as one's main object of literary study is at best a form of "harmless drudgery," as Frederick Cassidy once said of dialect research in mock self-deprecation. ${ }^{5}$

Scholarly interpretations of New England's cultural importance during America's Romantic era have particularly tended to minimize the centripetal aspect of New England ideology, as compared to that of other regionalisms. Indeed it is standard practice to reserve the term "regionalism" for New England culture in its post-Civil War phases alone. Benjamin Spencer, author of the most seminal discussions both of American literary nationalism and of American literary regionalism, declines to categorize the New England Renaissance as a regional movement, on the grounds that (1) such writers "referred seldom to a New England literature" but "were interested rather in glimpsing the oversoul in any object or in creating an American literature through any native media"; and (2) they "might reasonably assume that New England literature and American literature were all but synonymous." In this view, only after New England's political and literary power began significantly to wane, did New England regionalism develop. Although Spencer carefully refrains from making value judgments between regionalism and nationalism, his analysis implicitly valorizes the latter and associates the former with the produce of a second-rate culture. As regards New England writing, that verdict is echoed by our standard literary histories, which present Emerson, Thoreau, Hawthorne, and Dickinson as national literary heroes and consign Xankee regional realists to a catchall chapter. Likewise, turning to more specialized studies, We find R. W. B. Lewis on the American Adam, Sacvan Bercovitch on the American self, and Harold Bloom on American poetic influence locating New England origins for the important themes they chart but arguing for the importance of those themes on the basis of national significance, so that the provincial element finally becomes legitimated in proportion to its ability to transcend itself.

That New England Renaissance was more innovative than late-century local colorism and that it had a broader and longer transregional influence very few scholars would seek to deny. The point has been demonstrated many times over, by Emerson's influence on the Whitman 
tradition, Thoreau's on literary naturalists from John Muir through Gary Snyder, Hawthorne's on the Southern Renaissance, and Dickinson's on sundry modern poets. Nor is the notion of New England regionalism as mainly a late-century ideology a mere scholarly artifact. Despite such bursts of local patriotism as Margaret Fuller's "It was for dear New England that I wanted this review", it seems clear that antebellum New Englanders tended to think of literature as transregional both in the "bad" sense of wishing to stick closer than they should have to Anglo-European models (vide Longfellow) and in the "good" sense of insisting that genius transcends provincial categories (vide Emerson). "Coarse local distinctions, as those of nation, province or town," writes Emerson, "are useful in the absence of real ones; but we must not insist on these accidental lines." There is no reason to doubt that he meant exactly what he said.

At the same time, there is no reason for our taking him at his word, especially when we hear Emerson in other contexts proclaiming in "the language of coldest history" that "Boston, the capital of the Fathers, ... was appointed in the destiny of nations to lead the civilization of North America"; or speculating in the privacy of his journal that "It will happen by \& by, that the black man will only be destined for museums like the Dodo." Such moments help to define a core of Yankee Anglo-Saxon centripetalism in Emerson and to explain his first remark quoted above (from English Traits) not just as culture criticism but as self-criticism.

And also, we might add, as a typically Yankee kind of criticism. Here we come to the aspect of New England ecumenicalist thinking most in need of demystification. It was easier for Emerson than for, say, William Gilmore Simms to think in universalist terms and to see ethnocentricitry as someone else's problem precisely because of the ease with which New England writers could assume, as Spencer puts it, "that New England literature and American literature were all but synonymous." Van Wyck Brooks neatly sums up this mentality: "That New England was appointed to guide the nation, to civilize and humanize it, none of [the major antebellum New England writers] ever doubted."10 They could claim the oldest and most continuous cultural tradition in America, and also the closest ties to the mother country. As Romantic historian George Bancroft put it in his History of the United States, "the people of Massachusetts were almost exclusively of English origin; beyond any other colony, they loved the land of their ancestors; but their fond attachment made thern only the more sensitive to its tyraniay." In. other words, the clan to which Bancroft belongs wins whether you measure by Anglo or by American values (the assumption that they are at bottom the same being in itself increasingly characteristic of the elite Yankee outlook as the century brought more and more European immigrants into the northeast). When Emerson delivered his address on "The American Scholar," which a dyed-in-the-wool Yankee ethnic (Oliver Wendell Holmes) has persuaded modern-day readers to think of as "our 
intellectual Declaration of Independence," it was easy for him to purvey as the basis of his program an introspective individualism that is recognizably post-Puritan without being consciously aware of its being so. It seemed validated by the drift of republican thought, by the latest currents of European thinking, and by the cultural expansion of New England, whose movement westward was widely seen as "a crusade to extend Yankee culture," an extension of the New England ego, "I have been to Plymouth \& stood on the Rock," Emerson had written in his journal a few years before addressing the Harvard Phi Beta Kappa chapter, " $\&$ felt that it was grown more important by the growth of this nation in the minutes that I stood there" (JMN 4, p. 261). That pretty well sums up the average New England intellectual's view of the significance of westward expansion.

In short, the provincialism of New England Renaissance culture is confirmed by the very element that seemingly argues against it: New England's readiness to equate itself with the national spirit. Daniel Webster's assumption of the role of protector of national union in his historic debate with South Carolina Senator Robert Hayne over what amounted to a sectional issue was a more typical manifestation of New England-centeredness than the Garrisonian anti-unionism that marks Emerson's and Thoreau's protests against the Compromise of 1850. (The latter also had their antecedents, incidentally, just as Garrison's pacifism did, in the quasi-secessionist rumblings of the Federalist far right during the War of 1812, the last gasp of the nation's first major secessionist ferment, which Hayne tried to pin on Webster and which thereby provoked Webster to greater heights of rhetorical nationalism. ${ }^{13}$ ) Solyman Brown's principles of selectivity in his Essay on American Poetry, Samuel Kettell's in his Specimens of American Poetry, James Russell Lowell's in his $A$ Fable for Critics, and Rufus Griswold's in his various anthologies of "American" poetry and prose - these were more typical symptoms of Yankee-centeredness than 'Thoreau's more pugnacious locoeentrism.

That there was also a more overtly ethnocentric element underlying antebellum New England thinking, however, should not be minimized either. "We cannot answer for the Union," said Emerson with reference to the Fugitive Slave Law, "but we must keep Massachusetts true" - meaning "Massachusetts in all the quarters of her dispersion, as she is the mother of all the New England states, and as she sees her progeny scattered over the face of the land" (EW 11, pp. 110-11). Such a remark says a good deal about the limits of Emerson's sense of cultural identity, as does Thoreau's assumption that the readers of Walden will be "you ... who are said to live in New England."14

The tribal consciousness underlying these remarks, particularly Emersor's, suggests that provincial ideology is not just a matter of place but of race as well. Indeed regionalism and ethnicity are homologous and sometimes coextensive formations. Standard accounts of the two domains overlap to the point of indistinguishability, as we see if we set, 
for example, Josiah Royce's much-quoted definition of a "province" against J. Milton Yinger's definition of an "ethnic group":

A province shall mean any one part of a national domain, which is, geographically and socially, sufficiently unified to have a true consciousness of its own unity, to feel a pride in its own ideals and customs, and to possess a sense of its distinction from other parts of the country. ${ }^{15}$

An ethnic group, as I will use the term, is a segment of a larger society whose members are thought, by themselves and/or others, to have a common origin and to share important segments of a common culture and who, in addition, participate in shared activities in which the common origin and culture are significant ingredients. ${ }^{16}$

Both definitions include the following main elements, though the emphases differ somewhat: a sense of group distinctiveness, a sense of tradition, a sense of unity, and minority status. Altogether it might easily be argued that regionalism and ethnicity are analogous, overlapping forms of subculturation whose convergence has much to do with the cohesiveness of a regional. culture. It is probably no accident that the regions that American cultural geographers agree in seeing as most cohesive-New England, the South, and the Mormon district of the West-have inscribed in their mythographies the strongest traditions of racial hegemony. By contrast, modern attempts to characterize, for example, the Southwest and the Pacific Northwest as culture regions have been forced by the obvious presence of sharp ethnic diversity (Amerindian, Hispanic also in the former case) to rest their arguments more heavily on environmental influences alone ${ }^{17}$ Certainly in the case of New England culture, it is clear that the provincial self-consciousness had from the start a tribal as well as a merely spatial dimension to it; the conventions of the jeremiad, to cite a single illustration, make that clear.

Compared to that of the South, the New England subculture seems most distinctive, first, with respect to the fitfulness with which it has consciously perceived itself as a minority culture and, second (and related), in the tardiness with which it generated a theory of philosophical racism to defend itself. Although racism played a part in regional ideology from early colonial times, as is clear from the record of PuritanIndian relations, ${ }^{18}$ Anglo-Saxonism as an overt program emerged fullblown only in the late nineteenth century, as a response to the gains made by Irish and other immigrant groups. ${ }^{19} \mathrm{By}$ the Civil War we see the first signs of this in the leading authors - in Emerson's and Hawthorne's midlife Anglophilism, in Thoreau's asperity toward the Irish, and in the teutonism of Brahmin historiography. In these we see genteel refractions of the nativist movement and the outbreaks of mob violence it occasion- 
ally provoked, starting with the burning of the Ursuline Convent in Charlestown in 1834. Although not precisely demonstrable, it is very likely that the antebellum vogue of historical romances of Puritanism and the century-long cult of the idyllic New England village that first emerges at the time of Timothy Dwight's Greenfield Hill (1794) were quickened by the growing awareness of traditional New England as imminently a minority culture, a minority first within the nation and ultimately within the region itself. Lyman Beecher tried to receive the Pilgrim spirit in Boston as he warned against the Catholic menace in the midwest. John Quincy Adams, commemorating the bicentennial of the New England Confederation of 1643 , extolled it as "the model and prototype of the North American confederacy of 1774," one feels, as a way of making the best that New England was "daily declining in her influence as a component part of the Union" and had through secularization and through incorporation into the union "lost her distinctive character."

"One gradually grows to feel," as Barrett Wendell remarked at the turn of the century, "that only the passing of old New England made its literature possible." "21 The passing of Puritanism into history made historical literature about Puritanism possible; the economic and cultural marginalization of traditional village culture evoked the cult of the village, regional gothic, and local color realism; the loss of hegemony and distinctiveness in both religious and secular spheres drew the region's intellectual elite toward Anglo-Saxonism, as Hawthorne, for instance, after leaving Puritan history behind and after several halfhearted dramatizations of attempts to regenerate the New England of today in The House of the Seven Gables and The Blithedale Romance, attempted toward the end of his life to record in travel book and unfinished romance the "unspeakable yearning towards England" that "lies deep in the Anglo-American heart." 22 The dead end of this kind of thinking is to be found in such documents as the following passage from a turn-of-the-century sermon delivered in commemoration of Forefathers' Day, the traditional New England holiday (22 December) honoring the landing of the Pilgrims:

If the Pilgrim fathers were a righteous remnant, we their sons are certainly a minority. We are scattered throughout the land. We have lost control of New England. Faneuil Hall is in an Irish city. Many beautiful colonial dwellings under the elms are crowded with Slavs and Poles and Italians and French Canadians. The Roman Catholic spire overshadows the Meeting House. More than that, the Anglo-Saxon is now a minority; only a remnant is left of the sons of the Dutch and the Cavalier. ${ }^{23}$

The degeneration of New England follows, in this interpretation, directly from the dispersal of the once-master race. 
I have no desire to reduce traditional New England ideology simply to tribalism or to present the Very Reverend William Grosvenor as the authoritative spokesman for New England values. I point up the racial element, rather, in part because in order to be scrupulously honest, study of subculturation must underscore its repulsive as well as its most appetizing features, and also because the obvious inadequacy of the former extreme as a total explanation of the case points us in the direction of perceiving what may be the most fundamental insight that provincial ideology has to offer us as an American cultural explanation: its dialogic aspect. The rhetoric and ideology of literary subcultures, be they regional or ethnic or a convergence of both, take shape not merely by isolating aspects of their own specialness (of which race is morally the most questionable, at least when used by a hegemonic group to shore up threats to its dominance), but through a more or less implicit process of assimilation, reaction, mediation, and compromise. That is why no regional literature, including local colorism, is purely regionspecific. Literary subcultures arrive at their ideological orientations only as a result of defining themselves in relation to other subcultures (Sarah Josepha Hale's New Hampshire defined in her 1827 novel North. wood by comparison to South Carolina, the frontiersman's ethos as a position to be resisted by Timothy Dwight but adopted through selective filtration by Henry Thoreau) and in relation to posited larger wholes (New England historians such as George Bancroft and John G. Palfrey picturing its institutions as the cradle of republican institutions, John Crowe Ransom attempting to present the Agrarianism of the Fugitives as based on a transregional belief "that the rural life of America must be defended, and the world made safe for the farmers ${ }^{124}$ ). No matter whether such accommodations are more or less instinctual, like Thoreau's disdain for the Irish, or highly strategic, like Webster's reply to Hayne: The key point is that the dialogic process operates in both cases.

How far does it extend? How strong a literary force is subculturation, anyhow? We are all familiar with the academic-exercise quality of arguments over how much of a Southerner Poe was, how much of a Puritan Calvinist Melville was at heart, how "black" Ralph Ellison's consciousness is, and so forth. The persistent-and increasing-insistence of New England watchers from the time of John Quincy Adams to the present that New England was once more distinctive than it is today should awaken one to the possiblity that modern scholars who rely heavily on subculturation as a tool of analysis may be participating in a great tradition different from the one they envisaged: a tradition of attributing cultural coherence to an era that ascribed that unity to a still earlier period, and so on back. Critiques of Perry Miller's overemphasis of the distinctiveness of New England Covenant Theology within the framework of international Puritanism warn us of the excesses to which even the greatest scholarly minds can go when they start to think regionally. The problem is not so much that subculturation is in prin- 
ciple a myopic approach to Covenant Theology, for the approach as I have defined it and as Miller practiced it should force one to think in comparatist terms, but that in practice one is tempted to overstate the specialness of the local manifestations at the center of one's graze. Indeed the student of American subcultures labors under the threat of a double myopia: overemphasis on the tribe as opposed to the nation, and overemphasis on the indigenous as opposed to the imported.

Yet if, on the other hand, New England's example suggests, provincial consciousness sometimes increases as provincial distinctiveness wanes, then we should be wary of taking empirical evidence of limited and waning provincial difference as proof of the unimportance of provin. cialism as an intellectual force. ${ }^{26}$ What allows Hawthorne in The House of the Seven Gables and Faulkner in Absalom, Absalom to articulate full-blown myths of regional history is that the authors are emancipated enough from their provincial identifications to indulge in imaginative free play. So far as literary history is concerned, then, the relative sparsity and miscellaneousness of data confirming the persistence of provincial contrast on the behavioral level (e.g.. New England's low' homicide rate compared with the South's, regional contrasts in church affiliation, etc.) become for our purposes less crucial than the fictive appeal of the notion of provincial difference.

On this level, the study of New England literary culture as a provincialism seems to have wide applicability. Consider its analogy to Southem regionalism of the twentieth century. In many respects the Fugitive manifesto I'll Take $M y$ Stand (1930) reads like a reprise of motifs noted above. It too takes rise as an ambivalent response to modernism, which brings to consciousness the sense of the passing of an older indigenous civilization; it too defines regional distinctiveness in terms of a sort of pastoral utopia, religious and racial coherence, and greater continuity with European roots than is ascribed to the rest of America. Taking a broader view of the long-standing myth of Southern history, of which he sees the Southern Agrarians as the first important modern reinterpireters, F. Garvin Davenport, Jr., isolates four related concepts: "Union, Southern uniqueness, Southern mission, and Southern burden." Mutatis mutandis, these might also be taken as the main controls of New England literary mythography, which also attempts to fix the position of the New England stratin within an emerging national identity in such a way as both to proclaim its specialness and to acknowledge the burden of its legacy. The specific terms vary, of course - the New England burden being seen more as religious than as racial bigotry, for instance--but the categories are transposable. Undoubtedly that homology of perspective, more than any direct influence, accounts for the likeness with which Hawthorne and Faulkner deploy provincial gothic convention in Seven Gables and Absalom. Both are attempts to invoke, articulate, and thereby control and contain provincial myths of history, attempts that in their narrative stances balance the skepticism of the cosmopolitan out- 
sider against the perspective of the provincial, seen as caught in the grip of tradition long years after that tradition began to lapse into decay. Both, through the examples of Sutpen and Colonel/Judge Pyncheon, imply an identification of provincial mission with an ideology that represents a fusion of visionary idealism and capitalistic greed. This in turn implies much the same burden for provincial history: social inequity resulting from the masking of self-interest as grand "design." It is interesting that both Hawthorne and Faulkner thereby invoke a "democratic" ethos as a means of undercutting Sutpen and the Pyncheon dynasty even as they also identify the evils of both dynasts with what might be called democratic individualism. That Sutpen and Colonel/ Judge Pyncheon are thereby used as objects of a double critique of the old provincial order and the new capitalist order is added testimony to the importance of the double identity phenomenon in the provincial literary consciousness. Or perhaps "twofold marginalization" would be a better way of putting it, since the effect of the sense of dividedness is to distance the experiencer from either form of identification.

Carl Degler, in his excellent book on "the continuity of southern distinctiveness," compares this dividedness of identification to the double consciousness of the American minoxity person, the classic description of which is that of W. E. B. Du Bois: "One ever feels his twoness-an American, a Negro; two souls, two thoughts, two unreconciled strivings." ${ }^{128}$ The agony of twoness expressed here clearly exceeds those of the cases we have examined. White Protestant New Englanders of the early nineteenth century, such as Emerson or Harriet Beecher Stowe, who with relative ease could assume that they spoke for America or at least America's conscience, clearly did not suffer from the ongoing agony of self-division deseribed by Du Bois. But to the degree to which they began to question that convergence, to suspect that they might be members of a despised minority after all, some such doubleness became a potentiality. One of the most striking features of Uncle Tom's Cabin, for example, is its multilayered and somewhat conflieting juxtapositions of New England, Southern, and national values. New England traits are in some contexts exposed as narrowly provincial when confronted with Southern ways (e.g., the fate of Ophelia's effort to impose her regime on the St. Clare family); in other contexts, seen as hegemonic in a bad sense (Simon Legree and the St. Clare brothers as Stowe's chief exhibits of how slavery is sustained by ineffectual Yankee-nurtured liberalism or by misdirected Yankee will); and in still other contexts offered as the cure for the national disease (Stowe's idealization of the ethic of a purified evangelicalism imaged by New England-style domesticity).

Without pushing too far the analogy between the structure of regionally oriented thinking and that of American minority groups, one can see the study of the latter as illuminating the former in at least two ways. ${ }^{29}$ First, it cautions us against a facile "from provincial to national" approach to the subject. Just as there have been and probably will 
continue to be peaks of ethnic consciousness in black American writing: (the Harlem Renaissance, the Black Aesthetic movement of the $1960 \mathrm{~s}$ and 1970s), the development of provincial consciousness in New England writing waxed (during the colonial era), waned (during the early national era), waxed again (during; the nineteenth century), waned again (with literary modernism), and may prove in time to have waxed once more in our century. Second, the analogy can serve to caution us against the extremes of a one-sided view of dual identity (i.e., the definition of the authenticity and value of New England writing either in universalized or in particularistic terms) and against a one-sided view of the polarity itself either as the key to New England literary culture or as a cliché that can somehow be ignored.

Very likely the Puritan "gene" in American culture will always be considered as having a special importance relative to other strains, owing to its early strength and resultant influence on American civil religion. Very likely the same can be said of the place of Emerson and the other major New England writers of his era so far as American literary history is concerned. We cannot, in other words, get very far by studying New England's literary culture as a simple ethnocentrism. But neither can we avoid studying it in terms of its ethnocentrism. And even when we listen for that note, we are not ceasing to regard New England discourse as nationally formative or quintessential. Rather, we are putting ourselves in the position of being able to identify what is bound to seem increasingly its most nationally representative feature as America becomes increasingly pluralistic and the heyday of the Puritans increasingly remote.

\section{NOTES}

1. I have in mind especially the essays in Miller's Errand into the Wilderness (Cambridge: Harvard University. Press, 1956) and Bercovitch's The Puritan Origins of the American Self (New Haven, Conn.: Yale University Press, 1975) and The American Jeremiad (Madison: University of Wisconsin Press, 1978).

2. On this subject see especially Howard Mumford Jones, The Theory of American Literature (1948, rev. ed. Ithaca, N.Y.: Cornell University Press, 1965), pp. 79-117; and Jay B. Hubbell, Who Are the Major American Writers? Durham, N.C.: Duke University Press, 1972), pp. 75-114.

3. This matter is dealt with a. length in Chapters 8-11 of my forthcoming study New England Literary Culture: From Revolution Though Renaissance New York: Cambridge University Press).

4. In this regard see especially William Spengemann's review essay in Early American Literature, 16 (1981), 175-186.

Harvard Garland, Crumbling Idols, edited by Jane Johnson (1894; rpt. Cambridge: ism and University Press, 1960), p. 49; Frederick Cassidy, "American RegionalPor pert the Harmless Drudge," PMLA, 82 (1967), bibliography issue, pp. 12-19. take towars the strongest statement on record against the position I am about to 
"The Regional Novel and Its Future," A rizona Quarterly, 1:2 (Summer 1945), "Emerson, Thoreau, and Hawthorne have nothing to say about New England regionalism. Concord, America, the World, and the Cosmos are concentric circles of meaning" (p. 17).

6. Spencer, "Regionalism in American Literature," Regionalism in America, edited by Merrill Jensen (Madison: University of Wisconsin Press, 1951), p. 224; Spencer, The Quest for Nationality: An American Literary Campaign (Syracuse, N.Y.: Syracuse University Press, 1957), p. 264. The latter is the most authoritative study of American literary nationalism, the former the best survey of literary regionalism in historical perspective. The Jensen volume still stands as a monument of interdisciplinary study of the regional concept. For its most important predecessor, see Howard W. Odum and Harry Estill Moore, American Regionalism: A Cultural-Historical Approach to National Integration (New York: Holt, 1938). For two of its most important successors, see Wilbur Zelinsky, The Cultural Geography of the United States (Englewood Cliffs, N.J.: Prentice-Hall, 1973); and Raymond D. Gastil, Cultural Regions of the United States (Seattle: University of Washington Press, 1975). For a readable if impressionistic description of major literary culture regions, see John Gordon Burke, ed., Regional Perspectives: An Examination of America's Literary Heritage (Chicago: American Library Association, 1973).

7. Fuller, Letters, Vol. 2, edited by Robert Hudspeth (Ithaca, N.Y.: Cornell University Press), p. 131

8. The Complete Works of Ralph Waldo Emerson, Vol. 5, edited by Edward W. Emerson (Boston and New York: Houghton, 1903-4), p. 151. Cited hereafter
as $E W$.

9. Emerson, "Oration and Response," in Cephas Brainerd and Eveline Warber Brainerd, eds., The New England Society Orations: Addresses, Sermons and Poems Delivered Before the New England Society of New York, Vol. 2, (New York: Century, 1901), p. 379; Emerson, Journals and Miscellaneous Notebooks, Vol. 13 , edited by William H. Gilman et al. (Cambridge: Harvard University Press, 1960-82), p. 286. Cited hereafter as JMN.

10. Spencer, The Quest for Nationality, p. 264; The Flowering of New England (New York: Dutton, 1936), p. 528. Cf. Simms's Dedication to The Wigwam. and the Cabin (New York: Armstrong, 1856): "No one mind can fully or fairly illustrate the characteristics of any great country; and he who shall depict one section faithfully, has made his proper and sufficient contribution to the great work of national illustration" (p, 4). Not until the 1850s did the New England Romantics go that far, although at that point one hears echoes of Simms in such remarks as Hawthorne's to Horatio Bridge (1857) that "the States are too various and too extended to form really one country. New England is quite as large a lump of earth as my heart can really take in" (Bridge, Personal Recollections of Nathaniel Hawthorne [New York: Harper, 1893], p. 155).

11. History of the United States, Vol. 7 (Boston: Little, Brown, 1858), p. 38.

12. Holmes, Ralph Waldo Emerson, John Lothrop Motley (Boston and New York: Houghton, 1906), p. 88. Holmes's provincial frarne of reference becomes wholly apparent in the next sentence, which begins "Nothing like it had been heard in the halls of Harvard since...." For some of the cultural implications of New England's expansion see Richard Lyle Power, "A Crusade to Extend Yankee Culture, 1820-1865," New England Quarterly, 13 (1940), 638-53.

13. See Speeches of the Hon. Robert Y. Hayne and the Hon. Daniel Webster (Boston: Carter \& Hendee, 1830).

14. Thoreau, Walden, edited by J. Lyndon Shanley (Princeton, N.J.: Princeton University Press, 1971), p. 4.

15. Josiah Royce, "Provincialism," Race Questions, Provincialism, and Other American Problems (New York: Macmillan, 1908), p. 61. Quoted with general 
approval by Frederick Jackson Turner, in Avery Craven and Max Farrand, eds., The Significance of Sections in American History (New York: Holt, 1932), p. 45; and by Edwin R. Bingham and Glen A. Love in their introduction to Northwest Perspectives (Seattle: University of Washington Press, 1979), p. xy.

16. "Ethnicity in Complex Societies: Structural, Cultural, and Characterological Factors," in Lewis A. Coser and Otto N. Larson, eds., The Uses of Controversy in Sociology (New York: Free Press, 1976), p. 200.

17. For the Southwest, see Ross Calvin, Sky Determines (1934; rpt. Albu. querque: University of New Mexico Press, 1965); and Lynn I. Perrigo, The American Southwest (New York: Holt, 1971). For the Northwest, see Northwest Perspectives and V. L. O. Chittick, ed., Northwest Harvest: A Regional StockTaking (New York: Macmillan, 1948). For a survey of American culture regions, see Gastil, Cultural Regions, pp. 137-288.

18. G. E. Thomas, "Puritans, Indians, and the Concept of Race," New England Quarterly, 48 (1975), 3-27, provides a short overview of this controverted subject. The strongest case on the Puritans' behalf is put by Alden Vaughan, New England Frontier: Puritans and Indians, 1620-1675 (Boston: Little, Brown, 1965); the anti-Puritan position is pressed most vigorously in Francis Jennings, The Invasion of America (Chapel Hill: University of North Carolina Press, 1975).

19. See, for instance, Barbara Miller Solomon, Ancestors and lmmigrants: A Changing New England Tradition (Cambridge: Harvard University Press, 1956).

20. Adams, "The New England Confederacy of 1643," Massachusetts Historical Society Collections, 3rd ser., 9 (1846), 219, 222.

21. Barrett Wendell, A Literary History of America (New York: Scribner's, 1901), p. 462.

22. Hawthorne, Our Old Home, edited by William Charvat et al. (Columbus: Ohio State University Press, 1970), p. 18.

23. William M. Grosvenor, The Puritan Remnant (New York: privately printed, 1911), pp. 3-4.

24. Ransom, "Reconstructed but Unregenerate," in Louis D. Rubin, Jr., ed., Ill Take My Stand (1930; rpt. New York: Harper, 1962), p. 25.

25. See, for instance, David D. Hall, "Understanding the Puritans," in Herbert J. Bass, ed., The State of A merican History (Chicago: Quadrangle, 1970), pp. $330-49$.

26. Laurence Veysey, "Myth and Reality in Approaching American Regionalism," American Quarterly, 12 (1960), 31-43, comments thoughtfully on the relative merits of empirical and myth-oriented approaches to the subject. Carl Degler's Place Over Time: The Continuity of Southern Distinctiveness (Baton Rouge: Louisiana State University Press, 1977) impresses me as a model of tact. with regard to its weighing of empirical and subjective evidence, as well as in its avoidance of the pitfalls of over- and understatement of regional distinctiveness. A pair of essays on New England culture that in their antagonism reinforce the point I am making are George Wilson Pierson, "The Obstinate Concept of New England: A Study in Denudation," New England Quarterly, 28 (1955), 3-17, which argues that "New England is not so much a Region as an optical illusion" (p. 7), and Percy H. Boynton, "The Novel of Puritan Decay from Mrs. Stowe to John Marquand," ibid., 13 (1940), 626-37, which sees change in but no end to storytelling about "New England puritanism's fall from high estate" (p. 637). The logical inference seems to be that the strangeness of New England's obstinacy is itself partly' an optical illusion resulting from having taken the power of imagination insufficiently into account.

27. Davenport, The Myth of Southern History (Nashville: Vanderbilt Univeraity Press, 1970), p. 1.2 and passim.

28. Degler, Place Over Time, p. 127; Du Bois, The Souls of Black Folk (1903; rpt, Greenwich, Conn.: Fawcett, 1961), p. 17. 
29. The following discussions I have found particularly helpful here: Blyden Jackson's contribution to Jackson and Louis D. Rubin, Jr.'s Black Poetry in America (Baton Rouge: Louisiana State Univ. Press, 1974); Chapters 5-7 of Houston A. Baker, Jr., The Long Journey Back (Chicago: University of Chicago Press, 1980); Arnold Rampersad, "The Universal and the Particular in AfroAmerican Poetry," College Language Association Journal, 25 (1.981), 1-17; Peter. Bruck, "Protest, Universality, Blackness: Patterns of Argument in the Criticism of the Contemporary Afro-American Novel," in Bruck and Wolfgang Kaiser, eds., The Afro-American Novel Since 1960 (Amsterdam: Gruner, 1982), pp. 128. Roughly speaking, Jackson takes a "universalist" position that Rampersad articulately opposes; Baker makes a strong case for the inevitability of conceiving Afro-American literary history in terms of a national vs. particular dialectic, while Bruck points out how easily that dialectic becomes reduced to formula by both contending parties. 